Revista Iberoamericana, Vol. LXVIII, Núm. 201, Octubre-Diciembre 2002, 981-995

\title{
APUNTES DISLOCADOS SOBRE LOS ZORROS DE JOSÉ MARÍA ARGUEDAS*
}

\author{
POR \\ RODRIGO CÁNOVAS \\ Pontificia Universidad Católica de Chile
}

Al caminar hoy por la Plaza de Armas de Santiago de Chile, el desinhibido grupo de inmigrantes peruanos que transita vestido de sport, con ropa usada de USA (empleadas domésticas, jardineros, obreros de la construcción, muchos de ellos ilegales), nos evoca la figura de José María Arguedas quien en su última novela El zorro de arriba y el zorro de abajo (1971) mostraba esas almas errantes que bajaban desde la sierra para incorporarse al flujo citadino, marcado por el signo macabramente ambiguo de la modernidad. Esta vez, eso sí, a estos sujetos se les ve mucho más contentos y animosos que aquéllos que bajaban a Chimbote.

¿Qué ha sido de esa última novela de Arguedas en Chile? La pregunta se justifica por cuanto este escritor está ligado profundamente a nuestro país por lazos afectivos y literarios: pasó aquí largas temporadas, se casó con una chilena, hizo grandes amigos y también aquí recibió ayuda siquiátrica, que en algo lo alivió. Además, su obra tuvo una difusión privilegiada gracias a la publicación de Los ríos profundos y de Yawar Fiesta por la Editorial Universitaria (en la Colección Letras de América, dirigida por su amigo Pedro Lastra); lo cual lo ayudó, sin duda, a ser más conocido y respetado en todos los países de habla hispana.

En Chile, en el ámbito de la lectura (colegios, universidades, gran público), Arguedas vale por su novela Los ríos profundos (1958), donde el lector descubre la dimensión mítica de la vida andina. De El zorro hay escasísimas noticias: la crítica especializada tiende a ignorarla —notables excepciones son los trabajos de Leonidas Morales y, especialmente, de Mauricio Ostria-; poco se le menciona en aulas y seminarios (sólo lateralmente y siempre a propósito de la polémica con Cortázar, citada en sus Diarios) y no está visible en librerías; en fin, el lector chileno interesado en las letras hispanoamericanas la desconoce.

Quiero compartir mis impresiones sobre la recepción de El zorro, derivadas de la experiencia de incluir esta novela en mis cursos de literatura en estos últimos quince años en mi universidad — la Universidad Católica de Chile.

Lo primero es que el alumno demuestra poco interés por el tema indígena: le resulta ajeno o no lo asocia con el campo literario — como si en Chile no hubiera pueblos

\footnotetext{
* Este trabajo forma parte del proyecto Fondecyt №1990536 "Heterotopías: el prostíbulo en la
} novela hispanoamericana contemporánea”, del Consejo Nacional de Investigación, Conicyt, Chile. 
indígenas o una literatura que los cite, incluso, de modo bilingüe. Luego, los alumnos y alumnas chilenas tienden a dividir el libro en dos partes, una legible y truculenta (los Diarios, cuyas frases iniciales se refieren al suicidio) y otra ilegible y obscena (los Relatos y Hervores).

Entrenados en el verosímil de las vanguardias narrativas — Rayuela, El astillero, El obsceno pájaro de la noche - y gozando también de los subgéneros derivados del folletín - la novela negra, el relato de aventuras e, incluso, la novela rosa ilustrada-; estos lectores quedan petrificados ante los parlamentos del lobo Chaucato, el loco Moncada, el moribundo Esteban de la Cruz y del chanchero Bazalar. Y al leer la bibliografía crítica - que genera referentes culturales que sitúan la lectura: la oralidad, el forasterismo, el plurilingüismo, la carnavalización de las formas consagradas-, los estudiantes demuestran comprensión, pero no gusto... Aquí, el interés se desplaza desde la novela hacia el conjunto de textos andinos que ella alude o presupone.

Siniestramente, sólo el ensayo de Mario Vargas Llosa —el más alejado de la reconstitución de la escena andina de esta novela- les devuelve el entusiasmo y la curiosidad por El zorro: musitan (respaldados por una gran autoridad literaria; más encima, peruana) que, a nivel estético, el libro es un fracaso; puesto que falla en su registro de habla. No obstante - y repitiendo el gesto de Vargas Llosa—, su carácter escatológico y coprolálico les genera inquietud, lo cual los alienta (virtualmente) para emprender una relectura selectiva.

Estas son impresiones, especulaciones. Es difícil saber qué está pensando alguien — un estudiante, en posición de subordinado ante un texto impuesto y con la tarea de emitir un informe-; especialmente sobre un libro como éste. Me parece que los hombres muchachos y en particular, los más jóvenes- quedan profundamente impresionados por las escenas escabrosas, pensando acaso que no tienen parangón en la literatura chilena. Las mujeres, por el contrario, castigan a Arguedas con un cerrado silencio, como si la imaginería (sexual) del libro las excluyera. Excepcionalmente, algunos y algunas emprenden una lectura de corte antropológico y social.

Sirvan estas impresiones para otorgar un marco a nuestra lectura de El zorro, que estará centrada en dos aspectos: su recepción dentro de la crítica hispanoamericana y su lenguaje sexual. Estos dos aspectos forman parte de una reflexión amplia sobre la constitución del sujeto marginal y su posibilidad de trascendencia.

ARCAÍSMO Y MODERNIDAD

Como se sabe, la última novela de José María Arguedas es el relato de un suicidio. Como cualquier acto suicida con su nota previa —que en este caso aparecen mezclados, cual Happening —, esta obra es una apelación trágica a los seres queridos, quienes deben recomponer el puzzle — los trozos de una obra— incluyéndose en él. ¿Cómo ha transitado El zorro de arriba y el zorro de abajo en nuestra comunidad lectora? ¿Cómo hemos respondido a este llamado?

Consideramos que hay dos lecturas básicas de esta novela, irreconciliables entre sí: la lectura cosmopolita, que la compone desde los cánones de las vanguardias narrativas (presentada ejemplarmente por los comentarios críticos de Mario Vargas Llosa sobre la 
utopía arcaica) y la lectura andina, que descifra El zorro desde la cultura oral quechua en especial, los comentarios de Martin Lienhard y de Alberto Escobar, de base etnolingüística.

Hacia 1979 el escritor peruano Mario Vargas Llosa otorga una conferencia en Harvard University sobre el último libro de José María Arguedas, que fue publicada prontamente en la Revista iberoamericana con el título "Literatura y suicidio: el caso Arguedas”. A poco más de diez años del suicidio del autor —-falleció el 2 de diciembre de 1969- , éste quizás sea el primer trabajo de envergadura que comenta toda la novela (y no sólo los Diarios, su componente más legible), el más celebratorio y, paradójicamente, el que más lo denigra.

Vargas Llosa —acaso inspirándose en Marcel Bataille- lee El zorro como “un fresco del mal” (23), en cuanto exhibe los materiales reprimidos por la cultura, haciéndolos circular libremente, con su carga plena de lujuria y pudrición. Ahora bien, el drama de esta obra —y aquí esta la descalificación— es su “extravagancia lingüística” (25), que la torna casi ilegible. El proyecto de exhibir "el español mal aprendido de los indios” (22) falla, por la incapacidad de Arguedas de generar un lenguaje artístico alejado del verismo, síntoma de su dificultad para aceptar el progreso; todo lo cual transforma su experiencia artística en un acto afásico — que coincide con su suicidio y el eclipse definitivo de la utopía arcaica en la sociedad peruana.

Además del parentesco evidente de las posturas de Vargas Llosa y las de Cortázar (la adscripción a las formas vanguardistas como un modo de renovar una literatura regional leída en clave local), notamos una figuración cervantina en los comentarios críticos del joven peruano. Faltaría en Arguedas control narrativo, amén de artificio — como el que revela Basilio en las bodas de Quiteria, cuando torna creíble su muerte, gracias a su industria. Desde la nueva novela — como Cervantes contra las novelas de caballeríasse denuncia el lenguaje “disparatado" (26) de los personajes, amén de "lo estrambótico" (24) de sus acciones: "Un impulso que suele apoderarse de la gente es ponerse a danzar en las maneras y sitios menos aparentes, como la prostituta Orfa, explotada por Tinoco, al subir el arenal a la vuelta de su trabajo” (25).

La lectura andina es propuesta por el suizo Martin Lienhard, en una brillante investigación académica publicada en Lima en 1982, Cultura popular andina y forma novelesca. Zorros danzantes en la última novela de Arguedas. En este trabajo se demuestra la programación oriunda de esta novela, ligada a la continuidad de la cultura quechua - la cultura popular andina- que ilumina su anécdota, su espacio, su lenguaje y su forma. La cultura quechua actúa en el tramado de la obra como "materia prima que se destruye y reelabora” (133), estableciendo un diálogo entre el presente y el pasado, la escritura y la oralidad, el español y la diversidad sociolectal que lo descompone.

En esta lectura, los zorros danzantes de la novela no sólo dialogan con los zorros milenarios de Huarochirí; sino también con los danzantes de tijeras de Lucanas (en los carnavales actuales); lo cual implica que el signo novelístico (la tradición escrita) aparece descentrado e intervenido por un complejo sistema compuesto por signos verbales, musicales y gestuales (la tradición oral). A nivel espacial, desde el orden del Tawantinsuyu, Chimbote aparece dividido en un arriba y un abajo (los médanos y el puerto) y, a su vez, cada mitad en dos cuadrantes, como en el estado inca. Su compleja anécdota adquiere un 
sentido específico — sin por ello perder su carácter contradictorio y caótico- cuando se la interpreta como una alegoría andina que en una de sus versiones, por ejemplo, reza así: monos y lobos (el culemacho Brashi y el pincho Chaucato) se instalan en la concha-bahía (Chimbote, virgen ramera), para reinar sobre la mosca onquray onquray (los inmigrantes serranos, cojones de gato), en un espacio irredento —el prostíbulo, mundo al revés.

Así, el supuesto carácter estrambótico de cantos, bailes y parlamentos, y las extravagancias y porquerías de los actores participantes son entendidos, desde la lectura andina, como actos verosímiles, cuyas posibles incoherencias deben discutirse desde el código oral quechua. Siguiendo esta vertiente, es natural afirmar que el habla de los personajes asegura la legibilidad del texto, por cuanto sumerge al lector "en el universo verbal costeño" (104), gesto inédito en la literatura peruana.

Hacia 1984 el lingüista peruano Alberto Escobar publica un libro sobre Arguedas, que contiene un extenso capítulo sobre El zorro. Recordemos que en las líneas finales de su novela, José María le pide a este académico peruano que lea el Último Diario en el funeral. Desde la visión andina (que privilegia la oralidad), el aporte de Alberto Escobar consiste en el estudio de la diversidad de esta novela, desde la noción de sociolecto, la cual da cuenta del juego de connotaciones sociales de las formas orales que entretejen la obra; lo cual permite mostrar el carácter pluricultural y multilingüe de la comunidad peruana.

Atendiendo a los rasgos eminentemente orales de esta obra — en cuanto su lenguaje "corresponde a un sistema múltiple de recursos varios, verbales, cinéticos, melódicos y mixtos” (226) - Escobar propone redefinir su naturaleza (literaria) y su recepción (estética). Acudiendo a Lévi-Strauss, define El zorro más como un relato etnoliterario (articulado como un sistema de correlaciones orales cuyo código semántico es implícito) que como una obra literaria, de carácter autónomo. Y desde Lotman, considerando las actitudes connotativas de una comunidad lectora, define esta obra más como un objeto mítico que estético.

Las proposiciones de este connotado lingüista peruano pretenden resituar las censuras y malos entendidos en torno a este texto. Sus juicios tienen la virtud de poner en duda el canon literario impuesto por la llamada nueva novela hispanoamericana; sin embargo, es posible que exagere en cuanto a las proyecciones míticas de esta obra.

Hacia 1990 aparece una edición crítica de la novela, preparada por Eve-Marie Fell en la Colección Archivos de Unesco — por la cual nos guiamos-, que incluye el texto novelístico (y sus variantes), una selección de comentarios críticos y una documentación inédita del autor. Junto con celebrar esta publicación, queremos referirnos brevemente al texto crítico de Martin Lienhard allí incluido, “La 'andinización’ del vanguardismo urbano”, debido a que ofrece una variante de interés en la postulación de una lectura andina de El zorro.

Esta vez, Lienhard remarca el parentesco de esta obra con las del vanguardismo urbano occidental —léase Ulysses, Manhattan Transfer, et altri-, proponiendo "una convergencia de actitudes” (324), especialmente en cuanto al uso de procedimientos: "perspectiva múltiple, monólogo interior, ruptura de la secuencia causal, yuxtaposición de los registros lingüísticos” (329). En esta novela sería posible distinguir un polo vanguardista (literario), el cual es activado desde un segundo polo, el de la oralidad andina (indígena, misti y suburbana). El resultado del proceso es la andinización del vanguardismo urbano. 
Esta interpretación de Lienhard revela su interés de legitimar esa novela en un ámbito literario estricto, generando nuevos contextos de lectura que permitan sumar lectores provenientes de la otra orilla. Queda pendiente si la comunidad lectora ha aceptado este nuevo desafío.

No hay que pasar por alto las dudas y ansiedades que provoca en Arguedas escribir sobre la ciudad, íntimamente vinculada a su sentimiento de exclusión, no sólo social, étnico y lingüístico, sino también artístico. No nos cabe duda que su obra quiere competir con las de vanguardia, intentando la novedad. En este contexto, el suicidio, columna vertebral de la novela, puede leerse como un acto artístico vanguardista a lo andino, en la medida que el simulacro (fingir la muerte, morir fuera de la escritura) es sustituido por el rito (morir la vida, porque siempre se renacerá, en otro tiempo).

Nuestro escritor sabe que su proyecto es riesgoso, pues debe hablar sobre lo desconocido, odiado y temido: "Sí, pues. Creo no conocer bien las ciudades y estoy escribiendo sobre una. Pero ¿qué ciudad? ¡Chimbote, Chimbote, Chimbote!” (81). Este enunciado arguediano aparece partido en dos, cosa normal en él: escribe sobre una ciudad, pero ésta es Chimbote (la repetición del nombre la musicaliza, le otorga un rango intransitivo). Es como si se preguntara si realmente existe una ciudad andina, cual oximoron y esta consideración desencadenara una ambivalencia compulsiva.

Pareciera que Arguedas tiene miedo de no acceder al centro de la parte extranjera de Chimbote, acceso que podría facilitarse por las vivencias experimentadas en las grandes ciudades del mundo occidental: "en París creí entender todo y a todos —algo sé de cómo arden las ciudades, algo conozco de su verdadera pulpa” (82). Mal que mal, Cortázar diseñó su palacio en París y Vargas Llosa su casa verde en Londres: "Perdonen, amigos Cortázar, Fuentes, tú mismo Mario, que estás en Londres” (18).

Obviamente, el cosmopolitismo le resulta ajeno a José María; sin embargo, existe también el anhelo —-manifiesto en su Diario— de verse retratado fugazmente en él, como una manera oblicua de aparecer en la farándula del mundo. Ser visto, no ser olvidado, ser el punto blanco en la mitad negra (de la cosmópolis) y el punto negro en la mitad blanca (andina); esto también hervía en su cabeza. Acaso su anhelo fuera de que su libro y su muerte se leyeran como un mito en el Perú; mientras que se le entendiera como un acto vanguardista en la cosmópolis, nunca visto, un tapabocas a los falsos innovadores, blanco sobre blanco, cual Mallarmé.

Quizás sea éste el momento para constatar que los proyectos de Rayuela y de El zorro parten de una experiencia americana común de desarraigo, manifestada en oposiciones irreductibles (París y Buenos Aires, Paritía y Chimbote), en la búsqueda desesperada de sus personajes de la luz celestial - la mandala, los zorros - y en la comunión con el abismo: Horacio equilibrándose en una ventana del hospicio, José María escribiendo su Diario de muerte. En Rayuela el personaje juega a suicidarse (o quizás lo hace: recordemos el famoso "paf, se acabó”); mientras que su autor, cual taumaturgo, se salva a través del collage y el montaje, erigiendo un palacio, como en un cuento de hadas. En El zorro los personajes juegan a salvarse, en un rito programado por el autor para morir disgregado en la escritura y proyectarse en la vida bajo la forma de ruina, cual reliquia. ${ }^{1}$

\footnotetext{
${ }^{1}$ Un aporte al diálogo cultural de J.M. Arguedas con J. Cortázar, desde la comparación de sus novelas, lo entrega Mauricio Ostria: “La escisión cortazariana enfatiza lo espacial (la distancia como
} 
En 1996, Mario Vargas Llosa publica La utopía arcaica, que constituye una interpretación de toda la obra de José María Arguedas, dentro del marco del indigenismo. Su penúltimo capítulo — “Un mundo infernal” — transcribe su antigua conferencia de 1979 con mínimos injertos, dispuestos para reforzar su idea germinal: la obra es ilegible, conformándose como un cuerpo inverosímil tanto en sus registros de habla como en su forma novelística. En algunos de esos párrafos agregados, se refiere a las investigaciones del profesor Martin Lienhard, mostrando interés — por cierto- por los "argumentos persuasivos" (316) usados para hacer converger El zorro y Manhattan Transfer, lo cual otorga nuevas luces a su lectura cosmopolita: “es cierto que, en ambas historias, el protagonista es una ciudad, y que Chimbote aparece, en esta última, como Nueva York en aquélla, recreada mediante una técnica cubista, fragmentada y tumultuaria, y que en ambos libros hay más creación que documento” (316).

Muchos añadidos en este capítulo constituyen un reconocimiento implícito de ciertas codificaciones andinas — despejadas por Lienhard-, no reconocidas en su primera lectura. Como ejemplo, este párrafo referido al canto y la música: “Una de las señas de identidad es la urgencia de expresar las emociones y razones que animan a las gentes mediante el baile, lo que imprime a esta realidad un rasgo mágico” (320). Sin embargo, a este añadido le sigue otro que tiende a ridiculizar las fiestas andinas, por su carácter estrambótico, más aún si aparecen actuadas por un extranjero: “Maxwell, el ex cuerpo de paz, cuya conversión al andinismo ocurrió en el curso de una fiesta en una comunidad puneña y que desde entonces baila como poseído del espíritu de San Vito y toca charango como un nativo" (321).

Las lecturas cosmopolita y andina se revelan como las dos caras de Jano, que miman el gesto esquizoide del texto novelesco, el cual se genera como un cuerpo escindido en dos partes, atraídas y repelidas conjuntamente en el acto de una escritura suicida.

Desde los Diarios, Vargas Llosa se convierte en un doble de Cortázar, proclamando el fin de la utopía arcaica en nombre de las vanguardias artísticas. Y desde los Relatos y Hervores, Lienhard se confunde con el gringo Maxwell, ambos extranjeros andinizados que descubren para nosotros el origen desde la visión de los zorros danzantes en Paritía (en Maxwell) y en Lucanas — según experiencia vivida por Lienhard cuando realizaba sus investigaciones, de acuerdo a su propio testimonio. La continuidad de la cultura oral en la literatura peruana señalaría, entonces, el carácter utópico de los discursos vanguardistas, mensajeros de la modernidad capitalista.

Desde nuestra condición posmoderna, la lectura cosmopolita y la andina pueden rediseñarse desde las nociones de aldea global y de sociedad híbrida, y acaso ambas

separación); la de Arguedas, lo temporal (el pasado como pérdida cultural). Las figuras de integración son en Cortázar los puentes, las puertas, los túneles, los resquicios, las ventanas, todos elementos con valor de umbral o gozne, capaces de unir espacios discontinuos; en Arguedas, esos valores están representados por músicas, cantos y danzas (el zumbayllu, los zorrros danzantes), imágenes dinámicas, capaces de fundir tiempos diferentes. Cortázar privilegia las posibilidades gráficas, espaciales y visuales de la escritura, Arguedas evoca el carácter oral del quechua. Ambas posiciones representan cabalmente una doble problemática de la literatura, el arte y la cultura latinoamericanas: orfandad y lejanía, despojo y exilio, dolor raigal y sueño de vuelo, 'árboles y pájaros'. Doble camino de un mestizaje aún no resuelto” (Ostria 427-28). 
lecturas se imbriquen en la concepción de un gran mosaico cultural donde el marco (de relaciones sociales capitalistas, de carácter global) aparece constantemente desbordado por una imagen difícil de encuadrar, híbrida, marginal y fragmentada.

Es este sentimiento de imbricación el que anima, por ejemplo, un breve ejercicio de relectura de fin de siglo de Antonio Cornejo Polar (“Condición migrante e intertextualidad multicultural”, de 1995), maestro al cual ya le debíamos un texto crítico mayor sobre nuestro autor en la década de los setenta. Basándose en el forasterismo de Arguedas, "esa desasogante experiencia de ser hombre de varios mundos, pero a la larga de ninguno" (103); este crítico peruano se detiene en la condición migrante de los personajes de la novela, que nos remite a la constitución de un sujeto heterogéneo, intervenido por múltiples registros de habla: "imagino que el migrante estratifica sus experiencias de vida y que ni puede ni quiere fundirlas porque su naturaleza discontinua pone énfasis precisamente en la múltiple diversidad de esos tiempos y esos espacios y en los valores o defectividades de los unos y los otros” (104).

Muy recientemente, en el año 2000, aparece la primera versión al inglés de esta obra, The Fox from Up Above and the Fox from Down Below (con una traducción a cargo de Frances Barraclough, en una edición preparada por Julio Ortega, bajo el sello de The University of Pittsburgh Press). Desconozco si Arguedas habría concebido que en el futuro sus zorros tuvieran gran difusión en el país del Norte o que imaginara que su obra tuviera la capacidad virtual de iluminar ese paisaje lejano de Estados Unidos desde sus discontinuidades lingüísticas anglo-hispanas, sus superposiciones de códigos culturales (afroamericanos, chicanos, gentes venidas desde distintos puntos del Asia) y sus cuerpos migrantes. Justamente, en la Introducción, Julio Ortega sitúa la lectura actual de estos zorros, ya sea en Lima, Santiago de Chile o Nueva York, en el marco de la experiencia de la migración, entendida en su doble signo de pérdida y de regeneración vital:

\footnotetext{
Migrant heroes, like the very migration of meaning, are not merely victims, but axes of transformation and principles of rearticulation. That cultural practice is exercised in its capacity for survival, adaptation, and change via mechanisms of reapropriation (new information is processed and readapted), allowing the syncretic and cultural formations, even in discordant environments. (xix)
}

En el texto de Ortega destacamos su énfasis en el legado dialógico de Arguedas, sostenido por el gesto ético de un sujeto que reclama la palabra como un espacio de mutuo reconocimiento. Esta nueva humanidad del habla no tiene como actores a las voces instituidas, sino voces huérfanas que subvierten el mundo, desgarrándolo:

Thus, language is not an analytical consciousness but a confessional, a dramatic gesture of crude and uncertain emotivity. (xxi)

Finalizando esta breve y parcial incursión bibliográfica, mencionemos las notas escritas por Anne Lambright sobre lo femenino en la obra de Arguedas, tópico que no ha ocupado un lugar central en la bibliografía crítica. Ella propone una continuidad entre lo andino (indígena) y el elemento femenino del mundo, otorgándole a este elemento una cualidad purificadora: 
Indeed, if one interprets the feminine not strictly as a woman, but as nature, the maternal, the non-rational, and opposition to the dominant culture, as Arguedas does, the struggle of the feminine against the word of abajo becomes obvious. If the feminine here [in his last novel] loses the guiding power it had in the earlier novels, it is because Arguedas feels he is losing his word. (83)

Arguedas plasma en su obra de un modo dramático el desencuentro de dos mundos, el definitivo desprendimiento del significante de su significado trascendental. Este desprendimiento es también sentido hoy; aunque el hastío y el pragmatismo de nuestra actualidad convierten este drama en una comedia, una teleserie o en un lúdico ejercicio de video clip. Aún así, por nuestra condición de sujetos traslapados, de seres cosmopolitas barrocos, de soñadores letales; en fin, por nuestra vocación de huerfanía, José María Arguedas vuelve a instalarse en nuestro tiempo cotidiano.

\section{ZORROS Y ZORRAS}

El complejo registro lingüístico de esta obra se corresponde con un registro sexual dislocado, recreado en una atmósfera apocalíptica. Imágenes sexuales transgresivas anuncian un acabo de mundo; además de prohijar virtualmente un nuevo ser.

El sexo es presentado como un modelo reducido de los descalces de la cultura peruana, "una mezcolanza del morir y del amanecer" (51). Las escenas sexuales teatralizan - como los bailes, cantos y parlamentos de sus actores - el acto de procreación, insistiendo en sus variantes fallidas. El soporte material de estas escenas es un lenguaje escatológico, que hurga en los cuerpos hasta llegar al alma.

Arguedas convoca a los zorros míticos de Huarochirí — cuya presencia andina data de hace 2.500 años-, únicos capaces de descifrar Chimbote. Para ello, los zorros enmarcan esta historia contemporánea en dos escenas originarias: la protagonizada por Huatyacuri y la de Tutaykire, ambos hijos del dios Pariacaca. ${ }^{2}$

La primera escena es cuando los zorros se cruzan en el cerro Lautasaco. Junto al cuerpo dormido de Huatyacuri (hijo del dios Pariacaca), se refieren a la causa de la enfermedad de un poderoso señor del mundo de arriba, Tamtañamca, que simula ser dios: su mujer extrajo de su sexo un grano de maíz multicolor (que había saltado de una tostadora) y se lo dio de comer a un hombre. ${ }^{3}$ Huatyacuri escucha esta revelación y la

\footnotetext{
${ }^{2}$ Ambas escenas forman parte de una narración quechua recogida por el extirpador de idolatrías don Francisco de Avila hacia fines del siglo XVI en una provincia del Perú. Esta narración fue publicada en edición bilingüe en Lima en 1966 bajo el título Dioses y hombres de Huarochirí. La traducción la hizo José María Arguedas. En la Introducción, Arguedas indica que este texto quechua "es una especie de Popol Vuh de la antigüedad peruana; una pequeña biblia prehispánica de los pueblos que luego formaron el inmenso imperio colonial organizado en el Virreinato del Perú” (9).

${ }^{3}$ En la novela, este mito es resumido de modo muy apretado por el zorro de abajo, en su diálogo con su homólogo, hacia el final del Relato I, en páginas 49 y 50 . Copiaremos aquí algunas líneas del inicio de ese mito, tal cual aparece en el texto quechua, en una tradución que toma en cuenta las versiones de J.M. Arguedas y de Gerald Taylor: "La causa de la enfermedad es ésta: un grano de maíz muro (variedad multicolor) saltó del tiesto donde su mujer estaba tostando y cayó dentro de su sexo. La mujer extrajo el grano y se lo dio a comer a un hombre. Como el hombre comió el grano, se estableció
} 
aprovecha para curar al gran señor (falso dios), quedarse con su hija, vencer al yerno y castigar el adulterio, convirtiendo a la mujer en piedra, con su vagina visible. ${ }^{4}$

La otra escena es cuando en la conversación actual de los zorros, el de arriba evoca la figura del guerrero Tutaykire, también hijo de Pariacaca. Desde la novela, este zorro nos informa que Tutaykire "fue detenido por una virgen ramera que lo esperó con las piernas desnudas, abiertas, los senos descubiertos y un cántaro de chicha. Lo detuvo para hacerlo dormir y dispersarlo" (50).

Las dos escenas, de carácter sexual, se refieren a las reglas de la procreación y regeneración del mundo. Poco se ha comentado de la primera, indicándose que la acción mítica de Huatyacuri tiene escasa resonancia en la anécdota de la novela; a diferencia de la detención de Tutyakuri, héroe perdedor. ${ }^{5}$ Sin negar esto, es plausible proponer —en el nivel de los circuitos narrativos - una relación de continuidad entre Huatyacuri (que escucha la conversación de los zorros) y el diarista José María, que los escucha hablar de él mismo: "El individuo que pretendió quitarse la vida y escribe este libro era de arriba; tiene aún ima sapra sacudiéndose bajo su pecho” (50), dice uno de los zorros míticos. Con la ayuda de los zorros, Arguedas pretende pasar las pruebas impuestas por los falsos dioses y simuladores; para luego permitir la vuelta definitiva de los zorros (en un libro), tal como Pariacaca surgió de los cinco huevos, luego del triunfo de su hijo Huatyacuri. ${ }^{6}$

La segunda escena sexual parece encajar más armónicamente en el conjunto. Se ha indicado que este relato mítico recrea los avatares de la expansión territorial andina, la cual tiene su correlato en la novela en la inmigración serrana hacia la costa. Chimbote es una

entre ellos una relación culpable. Por esa falta es que una serpiente devora las cuerdas de la bellísima casa, y un sapo de dos cabezas habita bajo la piedra del moledor de maíz. Eso es lo que le está consumiendo. Así dijo el zorro de arriba; en seguida preguntó al otro: ¿Y los hombres de la región de los bajíos, cómo están?. Entonces el zorro de abajo contestó: Una mujer, hija de un sacro y poderoso jefe, casi murió por un pene (Pero el relato de cómo esa mujer pudo curarse es largo y lo escribiremos después, ahora volvamos a continuar lo que íbamos contando)" (Ortiz 177). Nótese que habría otro relato sexual —de la mujer y un pene-, que aparece interrumpido (acaso de poco interés para el extirpador y, por ende, dejado de lado). En la novela no se le menciona.

${ }^{4}$ En el texto quechua —en traducción que compone las versiones de Arguedas y de Taylor - este castigo se narra así: "[Huatyacuri] la persiguió, le dio alcance en el camino de la laguna de Anchi. Allí le habló: ‘Todos los hombres, los que bajan, los que suben, por este camino verán tu sexo'. Dicho esto, la colocó boca abajo en el suelo; al instante la mujer se convirtió en piedra. Y hasta ahora está esa piedra con sus piernas humanas y su vagina visibles; está sobre el camino. Los viajeros introducen coca en su sexo, hoy mismo, sí, por cualquier motivo” (Ortiz 180).

${ }^{5}$ Un valioso estudio de los mitos de Huarochirí citados en la novela es el de Ana María Gazzolo, por cuanto inquiere con mayor detenimiento sobre la relación entre sexo y mito. Consúltese también con provecho Cornejo Polar 1972, Rowe 1979 y 1996, Lienhard 1982 y Escobar 1984.

${ }^{6}$ Según el texto quechua de Dioses, Huatyacuri consulta a su padre, el dios Pariacaca (que aparece en forma de cinco huevos), para vencer en una competencia trascendental, y sólo cuando sale victorioso de ella, nace su padre: "Cuando terminaron estas hazañas de Huatyacuri, de los cinco huevos surgió Pariacaca (y sus múltiplos y hermanos), salieron en forma de cinco halcones. Luego se trocaron en hombres y se echaron a andar" (Ortiz 181). Así como los zorros anteceden a Arguedas (el mito a la historia, la oralidad a la escritura) y hacen posible su obra; éste los vuelve a concebir en la escritura. Y así como Pariacaca antecede a su hijo Huatyacuri (constituyéndose como la causa primera); éste le permite renacer, reinstaurando el origen de un modo teleológico. 
ramera que seduce a los forasteros, siendo la mar el sexo femenino que contiene, desde abajo, todo el orbe.

Si los zorros míticos sexualizan el relato; también lo hace el diarista, que abre su Primer Diario agradeciendo a una zamba gorda — prostituta, por cierto-haberle devuelto a la vida: "El encuentro con aquella alegre mujer debió de ser el toque sutil, complejísimo que mi cuerpo y alma necesitaban, para recuperar el roto vínculo con todas las cosas” (7). Y en el Segundo Diario se hará mención a un feliz encuentro en Nueva York con "una linda negrita” (81), a quien le habla en quechua: "La negrita me comprendió porque ella era una 'mariposa nocturna'” (81). Constatemos aquí que en los Diarios las prostitutas —zamba y negra - le otorgan un hálito de vida y esperanza al personaje; no siendo tanto así en los Relatos, salvo el caso de la Argentina, que brilla en su blancura cual lucero en la noche.

Finalmente, el sexo vertebra los Relatos y Hervores de la novela tanto en su soporte material (el lenguaje coprolálico) como en su dimensión simbólica (Chimbote como una zorra-bahía), al ser más explícito en las escenas del prostíbulo y de la boîte El Gato y al expresarse verbalmente en la boca de Chaucato, quien —al decir de un crítico- - "evoca la imagen del caníbal melancólico, que devora, para incorporar, pero destruyéndolo, a su objeto amoroso” (Gómez 366).

El prostíbulo chimbotano se abre como un mural grotesco, evocando La Katharsis, de José Clemente Orozco, con sus demenciales prostitutas representando los vicios de la sociedad. En el caso de Arguedas, sin embargo, la corrupción y el vicio se entremezclan con la pureza: "en la basura se encuentan los restos de los tiempos idos" (96).

A nivel alegórico, el prostíbulo representa la explotación capitalista: el dinero circula desde los pescadores a las putas — que funcionan como máquinas tragamonedas, presentes también en el burdel-, y de éstas a sus cafiches, para depositarse en Braschi, jefe de la mafia y gran capitalista. Ahora bien, el componente sexual no es agotado en esta alegoría. Es en este desborde sexual que se articulan las voces de trascendencia y negatividad, que enredan y tornan viscoso cualquier norma o mensaje unívoco. El prostíbulo es aquel espacio donde se exhibe el sexo endemoniado, donde el alma se debate en el cuerpo, en sus sentidos; espacio sagrado marcado por la desintegración cósmica.7

$\mathrm{Si}$ el sexo es una marca de origen, las relaciones que ocurren en este burdel - y por extensión, en el night club El Gato Negro- reconfiguran el origen como algo sucio, contaminándolo desde el ámbito de los sentidos (olfato, gusto, visión, tacto y oído). El ser andino se revela como un cuerpo sensorial constituido como un hálito de vida y, en su revés, como un estertor de muerte. Así, las caricias de la Narizota (con los pasos de Zavala escuchándose), la succión del Tarta (con el voyerismo del público), los dedos duros y caldeados de Fidela recorriendo el cuerpo terso del muchacho José María; todo este goce de los sentidos tiende a enviscarse y disolverse desde el miedo al contacto (Zavala temiendo el roce con el cuerpo anhelado), la visión de acoplamientos estériles (la Flaca mirando a la China con Chaucato) o el acto de devoración, con Braschi y el Mudo como agentes canibalísticos.

${ }^{7}$ En el plano numinoso, José Luis Rouillón distingue imágenes de horizontalidad, vinculadas a la experiencia sexual, e imágenes de verticalidad, vinculadas a la danza y a la música. El caos de Chimbote "se 'constriñe' en la guitarra de Crispín” (345); mientras que el rezo surge en plena experiencia sexual como gesto de redención y muerte. 
Entiéndase bien. El tiempo contemporáneo ha eclipsado la tradición andina (sin mancha), la cual sólo es rescatable desde sus vestigios, contenidos en imágenes sucias o espurias. Así, a nivel sexual, la humillación, el goce y la imprecación, aparecen imbricados generando un cuerpo andino dispar, pronto a ser abrasado (José María ante el tacto de la blancona), amamantado (el indio Asto pegado a la Argentina), o cegado por una visión endemoniada (un niño presenciando una fornicación forzada).

Esta configuración sensorial dislocada del cuerpo (sexual) aparece naturalmente conectada con una dislocación en el ámbito de la lengua y de la etnia. La lengua se configurará también como una imagen doble, reapareciendo una (el alma quechua) enterrada en otra (la norma del español) que la cita por fragmentos. No hay otra alternativa, no existe otro conocimiento sino aquél marcado por la agonía o la frágil sobrevivencia indígena manifestada en la sintaxis residual quechua en el habla de los personajes, en su radical desacomodo con el español, que le sirve de tumba-regazo. Insistamos: no hay modo de remover esa materia extraña (la lengua de Castilla), que todo lo contamina y por ende, cualquier rito de desapego de esa estructura presupone un rito de acoplamiento con ella, teñido de humillación y servidumbre. Sexo, etnia y lenguaje aparecen concebidos desde la contemporaneidad como espurios, un origen siempre contaminado; espacio irredento desde el cual se intenta una trascendencia por vestigios y fragmentos. ${ }^{8}$

Volviendo a las escenas sexuales del burdel y del club y ensayando un nuevo ordenamiento (que suplementa las aseveraciones anteriores y las disponen en un relato), proponemos que las acciones animadas por la Narizota, la Flaca, la China y la Caprichosa actúan esta agonía del cuerpo andino, sin poder regenerar la vida; pero aferrándose indisolublemente a ella a través del goce de los sentidos. Es la sensualidad enviscando a la muerte. ${ }^{9}$ En estricto rigor, estas escenas sexuales serían débiles resplandores de vida que retardan otra escena (que opera por ausencia, pues no aparece actuada), signo de muerte y de condena eterna: la del Mudo (homosexual y asesino) con la Muda (su madre puta) y Braschi (el poderoso, que tanto monta como se hace montar en el burdel).

\footnotetext{
${ }^{8}$ Se hace ineludible aquí la mención del pensamiento alegórico de Walter Benjamin, de base teológica. Al distinguir una expresión y su contenido trascendente como elementos separados que no conforman una unidad armónica, Benjamin señala la imposibilidad del signo de conectarse con el mundo trascendental y, por ende, la abolición del nexo del hombre con la divinidad. Al ser la Historia el tiempo de la Caída, la alegoría se erige como ruina, resto o reminiscencia de un tiempo primigenio. En el caso de Arguedas, su escritura descalzada —-la no correlación entre el mundo de abajo y el mundo de arriba - es la alegoría viviente de un mundo en ruinas, donde sólo las experiencias extremas conllevan visos de salvación.

${ }^{9}$ William Rowe es uno de los arguedianos que con mayor acierto ha explicitado las conecciones entre lenguaje, sexo y cuerpo en esta novela. Precisa que el énfasis en la prostitución —más allá de constituirse como una alegoría de la explotación - tendría también "el fin de simbolizar la sensualidad desconcertante de lo costeño desde el punto de vista serrano” $(1979,200)$. También Rowe propone una relación entre sexo y economía, desde la noción de producción, que resulta de interés: "La relación entre labor y capital se expresa como una cadena de fecundaciones: 'Yo hago parir a la mar' ('la mar es la más gran concha chupadora del mundo') mientras que los capitalistas 'hacen parir billetes a cada anchovetita'. Esta teoría de la plusvalía incluye la destrucción parasitaria de la fuerza de trabajo por el capital: 'miles y miles viven de [Braschi]; en cambio él le come las huevas"” (121).
} 
Braschi, dios falso que ha parido un nuevo mundo, es definido por sus orificios con el Mudo, son "hambrientos por el hueco” (27)_; calificándose por incorporar objetos y especies, destruyéndolos. Es un volcán (hoyo, culo, ano, chucha, boca), cuya erupción ocurre al revés; un volcán que retiene fuego y dinamita, lo cual le permite hacer parir. Es una boca tragona de gran voracidad, que procrea la mar como "la más grande concha chupadora del mundo" (26).

Braschi, creador del nuevo Chimbote, no actúa desde el pincho, metiendo huevo; como sí lo hace su subordinado Chaucato: "Yo comencé a miar primero en la bahía pa’Braschi: al agua limpita le metimos huevo” (28). Así, en esta cadena de asociaciones que conforma el mito de los nuevos orígenes, Braschi fecunda la mar a través de Chaucato, a su imagen y semejanza (la tragona), incorporando también a Chaucato a este acto (le come sus huevas). Braschi se erige como un hueco hambriento; mientras que Chaucato "el ojo izquierdo con el párpado bajo, algo caído y rojo; la boca igualmente algo caída por el mismo lado” (27) — es un animal marino parido sin capacidad de reproducirse — parido por lobos, con “los huevos redondos, pa’su desgracia” (52), según la Flaca.

El falso dios ha hecho de la mar una concha chupadora y de Chimbote un prostíbulo. Los habitantes de todos los reinos (arriba y abajo, mar y puerto, hombres y mujeres) le rinden culto a una waka de la estirpe de Caribdis. Lo sorprendente es que sólo entrando en ella se goza de los vestigios de todo lo añorado. El sexo es esa entrada, sensual y peligrosa, que corrompe y redime; cuyo reverso sublime es la danza y la música, único espacio pleno de felicidad o de dolor y melancolía. ${ }^{10}$

El relato vive amenazado por la disgregación (cuerpo comido, afasia, muerte) y es justamente este sentimiento agónico de pérdida el que nutre las almas arguedianas, dotándolas de una energía cósmica que se proyecta más allá de la muerte. Así, el conocimiento contemporáneo se gesta como una experiencia sensorial de destitución del conocimiento mítico. No hay vuelta atrás; salvo el ejercicio compulsivo del entierro y desentierro de los vestigios en medio de un paisaje endemoniado.

Sexo y saber aparecen finalmente superpuestos en las figuras de los zorros, que dan título a esta obra arguediana. La novela, género citadino de la modernidad, aparece intervenida (salvada) gracias a la mediación de los zorros míticos, depositarios de la regeneración andina. Ahora bien, estos zorros son entes sexualizados no sólo por las historias que cuentan; sino también, porque contienen a nivel literal el sexo femenino, las zorras, espacio concebido de un modo ambivalente.

\footnotetext{
${ }^{10}$ Ante ciertos motivos recurrentes — la succión y la mordedura, la nutrición (Tarta) y la incorporación destructiva del objeto (el Mudo, que junto con el Tarta resumen las compulsiones antagónicas de la fase oral: Tarta-Mudo), la alucinación del seno materno como un principio devorador-, uno se vería tentado a realizar una lectura psicoanalítica del lenguaje y las acciones sexuales del texto; más aún si Arguedas fue un paciente siquiátrico y, se puede especular, estaría familiarizado con la jerga —recordemos el inicio del Primer Diario: "En mayo de 1944 hizo crisis una dolencia síquica contraída en la infacia y estuve casi cinco años neutralizado para escribir” (7). Una lectura psicoanalítica demasiado estricta sería, sin embargo, un error; puesto que normalizaría el texto, “comiéndolo”, quitándole así la posibilidad de que circule como un resto del cual uno no puede deshacerse. Eso sí, es deseable generar una red de asociaciones con el discurso cultural del psicoanálisis lo más libre posible, la cual, intersectada con otras redes —el mito, el cristianismo, la lengua materna - iluminará el destino arguediano.
} 
Los zorros son figuras escurridizas que pretenden dar vuelta al mundo y regenerarlo en una escritura llena de huecos, de escisiones trágicas y de circularidades regresivas. En estas migraciones internas andinas, los zorros (el conocimiento masculino) han tenido la compañía, desde su origen, de las zorras (la sexualidad, femenina). En los tiempos antiguos, las zorras ayudaron a regenerar el equilibrio armónico del mundo, ya sea mediante el adulterio (señal de la presencia de un dios impostor, al que hay que sancionar junto con su mujer adúltera) o por la seducción (señal de un nuevo orden, del cual es portador la seductora). Recordemos que en el primer caso, la historia de Huatyacuri, la adúltera es condenada a prostituirse a perpetuidad: es convertida en piedra a la orilla de un camino, con sus piernas abiertas, para que los viajeros introduzcan coca en su sexo, en un acto ritual de reafirmación de la masculinidad del orden primigenio. En el segundo caso, del guerrero Tutaykire, la seductora se erige como virgen ramera a quien hay que rendirle culto.

¿De qué manera estas escenas originarias iluminan el puerto de Chimbote en la actualidad? Entendiendo que el mundo arguediano funciona por constantes descalces y desplazamientos, proponemos por ahora los siguientes arreglos textuales para este puzzle. ${ }^{11}$ Para enunciar la imagen humillada del indio, se acude a la condena sufrida por la mujer adúltera en el mito, del cual hay una cita oblicua en el espacio de mayor podredumbre y degradación del burdel, cuando se nos indica que desde los cuartuchos infectos del corral las prostitutas se muestran "con las piernas abiertas, mostrando el sexo, la 'zorra', afeitada o no” (40), cual figuras idolátricas tallada en piedra. El cuerpo andino en su integridad es embutido en esta imagen, siendo entonces representado como cuerpo castrado, sodomizado y prostituido por la modernidad.

Sin embargo, siempre ha existido, desde los orígenes, una apertura sensorial del cuerpo andino, que regenera el mundo, como el caso del encuentro de Tutaykire con la virgen ramera, citado en la actualidad, por ejemplo, en el feliz encuentro del indio Asto con la Argentina o en aquel otro, más ansioso, entre el joven José María y Fidela. Ahora bien, al parecer este camino de las vírgenes rameras conlleva riesgos insospechados, acaso ligados a miedos atávicos ante la imagen femenina. Esta amenaza es resuelta de un modo armónico cuando el impulso de lo nuevo es generado desde la dinámica interna del orden andino. Así, Fidela y la Argentina pertenecerían a la serie de seductoras que otorgan un nuevo sentido a la vida andina, aun cuando también traigan cierta zozobra por el poder sexual que ejercen - recordemos la angustia vivificante del muchacho José María y la sonrisa beatífica del indio Asto. No obstante, cuando el impulso nuevo no logra ser integrado en el orden andino, surge la imagen terrible de Caribdis, que destituye tanto el principio masculino como el femenino, dejando en escena sólo cuerpos aferrados a una

\footnotetext{
${ }^{11}$ Mencionemos aquí el sugerente trabajo de Claudette Kemper Columbus, que lee estos mitos de fecundación en el contexto de la novela, tanto como actos de posesión destructiva como de regeneración vital andina: "Arguedas depicts time and sexuality past and present, and agrarian and capitalistic exchange, both as possesion (forms of violation and exploitation) and as surplus (revivification and regeneration) through the mythic beings of the foxes; through the mytic deities, the hiperreal shaman healer artists Huatacuri and Tutaykire; through personal memories; and through characters ‘taken' from life” (122).
} 
sensorialidad precaria, que actúan una trabada búsqueda de infinito: el zambo Mendiata, Zavala, la Narizota, el Tarta.

A manera de colofón. La escritura de esta novela plantea desafíos inconmensurables al lector, por cuanto presenta una textura rota que sólo es posible restaurar a pedazos desde una lógica emocional, que tenga en cuenta estados de ánimo, voces que se escuchan dentro de nuestras cabezas, lagunas mentales y, singularmente, el sufrimiento humano y su variante más radical, el dolor síquico. Arguedas nos lanza de cabeza a un mundo deshumanizado, con la esperanza de que nos reconozcamos en ese paisaje. La lectura se transforma, entonces, en un acto de trascendencia negativa: sólo sabiendo que estamos en el infierno, podremos quizás desfondarlo para tocar el cielo.

\section{BiBLIOGRAFÍA}

Arguedas, José María. El zorro de arriba y el zorro de abajo. Eve-Marie Fell, ed. Paris: Colección Archivos, Unesco, 1997.

The Fox from Up Above and the Fox from Down Below. Julio Ortega, ed., translated by Frances Horning Barraclough, critical essays translated by Fred Fornoff. Paris: Colección Archivos, Unesco/Pittsburgh: The University of Pittsburgh Press, 2000.

Avila, Francisco de. Dioses y hombres de Huarochirí. Traducción del quechua de J.M. Arguedas. Lima: Instituto de Estudios Peruanos, 1966.

Benjamin, Walter. “Allegory and Trauerspiel”. The Origin of German Tragic Drama. John Osborne, trad. Nueva York/Londres: Verso, 1998. 159-235.

Columbus, Claudette Kemper. “Grounds for Decolonization: Arguedas's Foxes”. Genealogy and Literature. Lee Quinby, ed. Minneapolis/Londres: University of Minnesota, 1995. 116-33.

Cornejo Polar, Antonio. Los universos narrativos de José María Arguedas. Lima: Horizonte, 1972.

“Condición migrante e intertextualidad multicultural: el caso Arguedas”. Revista de Crítica Literaria Latinoamericana 42 (segundo semestre 1995): 101-109.

Escobar, Alberto. Arguedas o la utopía de la lengua. Lima: Instituto de Estudios Peruanos, 1984.

Gazzolo, Ana María. “La corriente mítica en El zorro de arriba y el zorro de abajo de José María Arguedas”. Cuadernos hispanoamericanos 469-470 (julio-agosto 1989): 4372.

Gómez, Edmundo. “Todas las lenguas. Vida y muerte de la escritura en 'Los zorros’ de J.M. Arguedas”. El zorro de arriba y el zorro de abajo. Eve-Marie Fell, ed. Paris: Colección Archivos, Unesco, 1997. 360-68.

Lambright, Anne. "Losing ground: some notes on the feminine in El zorro de arriba y el zorro de abajo”. Hispanofilia 122 (1998): 43-72.

Lienhard, Martin. Cultura popular andina y forma novelesca. Zorros y danzantes en la última novela de Arguedas. Lima: Latinoamericana, 1982.

Lienhard, Martin. “La 'andinización’ del vanguardismo urbano”. El zorro de arriba y el zorro de abajo. Eve-Marie Fell, ed. Paris: Colección Archivos, Unesco, 1997. 32132. 
Morales, Leonidas. “José María Arguedas: el lenguaje como perfección humana”. Estudios Filológicos 7 (1971): 133-43.

Ortega, Julio. “Introduction”. The Fox from Up Above and the Fox from Down Below. Julio Ortega, ed., translated by Frances Horning Barraclough, critical essays translated by Fred Fornoff. Paris: Colección Archivos, Unesco/Pittsburgh: The University of Pittsburgh Press, 2000. xi-xxxi.

Ortiz, Alejandro. El quechua y el aymara. Madrid: Mapfre, 1992.

Ostria, Mauricio. “José María Arguedas o la escritura contra la muerte. Construcción y desconstrucción de un verosímil narrativo”. Acta literaria 6 (1981): 39-55.

Ostria, Mauricio. "Sistemas literarios latinoamericanos: la polémica Arguedas/Cortázar treinta años después”. Crisis, apocalipsis y utopías. Fines de siglo en la literatura latinoamericana. Rodrigo Cánovas y Roberto Hozven (eds.). Actas del XXXII Congreso del Instituto Internacional de Literatura Iberoamericana. Santiago: Instituto de Letras, Universidad Católica de Chile, 2000. 423-28.

Rochlitz, Rainer. “Aesthetics of the Sublime”. The Disenchantment of Art. The Philosophy of Walter Benjamin. Jane Marie Todd, trad. Nueva York/Londres: The Guilford Press, 1996. 48-113.

Rouillón, José Luis. "La luz que nadie apagará. Aproximaciones al mito y al cristianismo en el último Arguedas”. El zorro de arriba y el zorro de abajo. Eve-Marie Fell, ed. Paris: Colección Archivos, Unesco, 1997. 341-57.

Rowe, William. Mito e ideología en la obra de José María Arguedas. Lima: Instituto Nacional de Cultura, 1979.

Rowe, William. Ensayos arguedianos. Lima: Sur, 1996.

Vargas Llosa, Mario. “Literatura y suicidio: el caso Arguedas”. Revista Iberoamericana 110-111 (enero-junio 1980): 3-28.

Vargas Llosa, Mario. “Un mundo infernal”. La utopía arcaica. José María Arguedas y las ficciones del indigenismo. México: Fondo de Cultura Económica, 1996. 296-326. 